\title{
The people and the Wayang by Franz Magnis Suseno: translation and introduction by Verena H. Meyer
}

Ratna Lahiri ${ }^{1,2,3,4,5}$ (D)

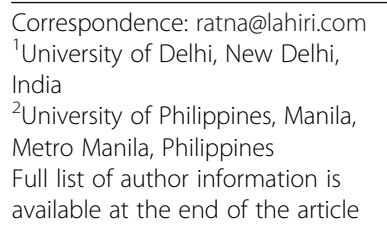

\section{Book details \\ This is a review of the much awaited "Kita dan Wayang" (Jakarta: Lembaga Penunjang Pembangunan Nasional, 1982, ISBN 9795113062; ASIN: B0000D7HUU), an interpretation of the Indonesian puppet theatre texts, written by Franz Magnis Suseno, a scholar-priest and activist settled in Indonesia, and its English version, translated with an introduction by Verena Meyer, a research scholar in the field (International Journal of Dharma Studies, 2016, 4:3 DOI: 10.1186/s40613-016-0028-6).}

Keywords: Franz Magnis Suseno, Wayang, Indonesia, Wayang Kulit, Mahābhārata, Arjuna

The book discusses the age old tradition of the Wayang, the narrative musical performance of leather puppets in Indonesia, its intimate connection with the understanding of Indonesian Culture, as well as its relevance to current political and social issues. It has been translated for the English reader, with an introduction by the translator, indicating the immense relevance of the Wayang and its retellings for the understanding of post Suharto's Indonesia. Post Suharto there was a call for change in the centralized methods of governance in favor of more democratization at provincial and village levels. An attempt to make this happened in the reforms that were adopted subsequently, but then the lack of proper supervision and coordination resulted in the local satraps and their cohorts cornering the benefits instead of the people for whom it was meant. The author warns against any passive acceptance of whatever happens politically and strongly advocates active protests in case any injustice is being done.

The author is a Jesuit Priest who has made Indonesia his home and understands Indonesian culture to its core. He belongs to the Dryakara School of Philosophy, and is much revered both as a scholar of Indonesian culture as well as a social and political activist. He has studied the Wayang tradition deeply, since it permeates every field of Indonesian Life, social ethical and political. The author is also a professor of Philosophy and a well respected and popular figure in Indonesia, since his concerns for social justice are well known and appreciated.

Perceiving the immense importance and influence of the Wayang on daily life, its imagery and accepted behavioral norms in the local Indonesian culture, he has chosen to point out the possible misconceptions regarding the message of the Wayang, and 
uses his acumen to point out how the proper understanding of the traditional Wayang itself can help his fellow citizens to participate in reforming society, by introspection as well as appropriate action at the right time. According to the author, some of the Wayang may be misinterpreted to imply that we should limit ourselves to minding our own business. The Indonesian then tends to stay within his sphere of duties as he believes them to be ordained by fate and does not oppose that which he thinks is beyond his domain. It is interesting to note that in his final analysis, the author avers that this non-interference in social issues is not really what the Wayang wishes to convey, since Kresna (Krishna) always take things in hand to provide solutions.

The author points out how the Wayang can be and sometimes is misunderstood by the spectator as indicating a non-involvement in social and political issues. "... We are tempted to limit ourselves to the role of the spectator, when we let anything happen. ... People also easily misinterpret the reality of Wayang stories when they think that the fate and the duties of all figures have already been determined. The truth is that fate simply cannot be known because it is as though it is decided behind the stage. Therefore, the attitude of surrender to all conditions is actually wrong - and is not justified in the Wayang. It is precisely by assuming responsibility for the things around us that we encounter what has been determined for us, we find our own duties by behaving in a way that is appropriate for whatever it is our responsibilities demand from us".

While the understanding of the Wayang kulit and its symbolism is not a new subject for scholars of Indonesian culture, what makes this particular work important for a deeper understanding of the Wayang in relation to the Indonesian situation is indicated aptly in the introduction by the translator. "The People and the Wayang (1982) is an example of a renegotiation and reinterpretation of a myth in a way that responds to the context of Javanese society in the years of Suharto's New Order. The ethics it formulates are primarily addressed to an Indonesian audience at a particular time, but also articulate a kind of humanism with a Javanese stamp."

It does all this and much more. Firstly the author makes it abundantly clear as to how the indigenization of Ramayana and Mahabharata is complete in the way the Indonesian thinks about the tensions between the major characters like Beema (Bheema), Karna, Suyodana (Duryodhana of the Mahabharata), and Kumbakarna and Vibisana (Kumbhkarna and Vibhishana from the Ramayana). None of the characters can withstand total ethical scrutiny as life presents them with choices in shades of grey and there are no easy black and white answers. The author is able to discern this peculiarity of real life situations that the Indonesian character appreciates fully. Real life conflicts, as between the loyalty of a warrior on the 'wrong' side of the ethical dilemma, and the unfairness of the double standards applied for the favored and un-favored sides of a conflict, are brought out clearly. This forces an understanding spectator to think for himself, rather than just watch passively. Instead of painting the Kurava (Kauravas) black or the Pandawas ( Pandavas) as totally ethical, the Wayang shows the dilemmas facing both sides that have to cross the ethical line due to some personal compulsion. Everyone has his own dilemmas and so we must not paint anyone totally black or white. As opposed to the Indian Mahabharata, where the Pandavas can do no wrong since they are favored by Krishna, the Wayang reveals how both sides act according to compulsions and there are no out and out evil characters. So one must think and decide about every situation after deep introspection and analysis. 
Thus the Wayang is not just a moralistic text. It eggs the viewer on to think for himself, and realize the dilemma of both sides of the issues. While many articles and books have been written about the symbolic, spiritual, ethical, aesthetic and philosophical values of the various themes presented in a Wayang performance, the author brings out specifically how it is much deeper than just a war between the good and the evil forces and certainly not just for entertainment. We need to constantly mull over the various presentations of the Wayang to make it relevant to present day issues. It reveals how the average audience is consistently informed of Indonesian cultural and ethical values through the Wayang, and how insistent the Wayang itself is in its preference for a self-searching and inward contemplation as opposed to a black and white perception of the situation.

Every performance is open to interpretations in relation to issues and concerns relevant to the present and some are made relevant in every presentation by the expertise and understanding of the major puppeteer/narrator, the Dalang. Along with the dilemmas arising out of new socio-ethical and political situations, he may or may not inspire the audience to introspect on political or local issues. However, it is up to the viewer as well, as to how he wishes to respond to the innuendoes in the interpretation. In that sense the Wayang is more performance oriented than the texts, because the acumen and understanding of both the presenter and the audience come into play to make each presentation a unique experience.

\section{A deep understanding of the source books}

That the author has a deep understanding of the source books of Ramayana and Mahabharata as well, is evident in his comparison of the two. The author's assessment of the Wayang tradition and therefore of the Indonesian mindset, implies that the Indonesian character is more appreciative of the circumstantial compulsions of the evil doer, and is therefore more tolerant and less judgmental. The Pandawas are loveable characters due to their charming bearing, good behavior towards elders and people in general; then they are the progenitors of Indonesian royalty. However, the Indonesian appreciates the dilemmas of Karna, Kumbakarana and Sengkuni (Shakuni) for that matter, as being more akin to real life situations, where the cause to be defended may conflict with personal loyalty issues. The same conflict arises also in the beginning of the Baratayuda (BharataYuddha) war, when Kresna (Krishna) and Karna appear before Dewi Kunti. Kresna (Kishna) tries to persuade Karna to join the Pandawa. He argues that Karna is really the oldest brother of the Pandawa and that truth is on the side of the Pandawa. And also Karna's mother, Dewi Kunti, gives him the same advice. Although Karna refuses to listen, he does not deny that truth lies on the side of the Pandawa. He clearly knows that the Kurawa (Kauravas) will lose in the end, but still feels that it is his duty to choose their side because he is indebted to Suyodana, who has given him the kingdom of Ngawangga (Anga Rajya), and thus he has pledged his loyalty to him." This analytical assessment of the Wayang reveals the author's deep understanding of Indonesian society and he takes this opportunity to exhort his countrymen to appreciate the real thrust towards an intelligent balanced activism of sorts and participation in voicing their grievances where needed, like Krishna, as part of the self-awareness that is developed by experiencing the Wayang.

As a Jesuit priest, the author may have certain compulsions, but since he is advocating a preference for social justice and thoughtful action, which happen to be important to the order as well as to the situation in Indonesia, this does not contradict the theme 
of the Wayang greatly. The other compulsions of Jesuit dogma, like adhering to the apostolic succession, opposing the Church of England or of being anti reformist, do not infringe upon the text of the Wayang, or the author's assessment of it. The new reforms not having brought the desired Justice, the author exhorts the people again and again to take considered action if needed. In this he perhaps plays the role similar to the Dalang who can interpret and slant the texts to imply a certain direction to the thought and responses of the spectators, and acts as per his political leanings of studied activism. The Wayang in Indonesia and the epics in India are open to such reinterpretations from time to time as long as the original storyline is not disturbed, hence there should be no objection to that. The author encourages the people to think how they should use the Wayang to understand their own political situation, and like Krishna, take matters in hand if need be.

\section{The analysis of the 'Carangan' scenes}

The analysis of the introduction of the "carangan" scenes again reveals how the Indonesian imagination has worked beyond the Baratayuda (Mahabharata) stories and introduced completely new themes and characters which can entertain as well as relax the public. The monsters in these 'side episodes' unrelated to the original, belong to a different world and are there to be killed by the warriors, to relieve the dark tensions of the Baratauyda deaths as it were. They appear and reappear to provide this relief again and again.

\section{The role of Semar and the Punakawan}

Last but not the least is the author's assessment of the role of the Punakawan, or Semar and his adopted sons, who seemingly play an incidental role but are vital to the characters that need moments of guidance when in trouble, or bits of laughter to cheer them up in difficult times. These are totally indigenous characters of Indonesian origin and at first seem to provide comic relief. The author has clarified how Semar may appear like a comic relief at first, but essentially he is a god above all gods in a way, intervening when matters seem hopeless but giving the right direction to the characters. $\mathrm{He}$ is also the protector of Pandawas, the progenitors of the Indonesian Royalty, and therefore of Indonesia. It may not be possible, however, for everyone to agree with his interpretation of the Wayang as leading to an escathon, and its comparison with the German "Götterdämmerung". Though the Mahabharata does lead to an apocalypse of sorts for the Pandawas and the Kauravas who are more or less wiped out; but the world goes on. The Asian poetical theories of epics demands that the story end with some kind of closure, in shaanta rasa, or the peaceful mode. Besides the very purpose of both the original Puranas and the Wayang traditions are to indicate a balanced guidance for all possible human predicaments in future, with a possibility of future regeneration, and not of hopelessness beyond repair.

In the end the author specifically discusses how the character of the maverick Semar is important to understand the philosophical or religious attitudes emphasized in the Wayang, and which are an asset to Indonesian character as well. Firstly, it emphasizes the fact that elitism, outward good manners or formal education is not necessarily the sign of a good heart. The higher valued Semar often misbehaves, is uncouthly dressed and as lowly as the common man, but without his advice the Pandawas would be lost. 
$\mathrm{He}$ is the real strength just as the common people are the real divine power behind the throne, the palace and all the paraphernalia that seems centered around the palace. The common people are the ones that bear the brunt of Natural disasters, they are the ones reflecting unselfish helpful values and are happy to do their work without expectation of reward. They know that ultimately it is Kiai Lurah Semar, Arjuna's guardian angel, that helps him win the war and all the tasks he would not have otherwise succeeded in. This attitude of surrender perhaps breeds the essential Javanese humility and is a value being transmitted through the Wayang performances. Thus, in giving an extremely balanced interpretation to the relevance of the Wayang to life in general, and particularly in one's approach to contemporary issues, the author has surpassed many assessments of the traditional Wayang. Though it is partly a political comment on post Suharto Indonesia, it also reflects more of an understanding of the deeper lifelong moral-ethical and timeless human issues which is what both the original Mahabharata as well as the Wayang tradition illustrate. This is why they are open to reinterpretation in accordance with the changing times, and this is why they remain relevant forever. This book itself is rated five star on various portals, and a short survey of its download demand online as an e-book indicates how much a good translation of it in English was awaited. It looks like that demand will now be fulfilled.

Competing interests

The author declares that he/she has no competing interests.

Author details

${ }^{1}$ University of Delhi, New Delhi, India. ${ }^{2}$ University of Philippines, Manila, Metro Manila, Philippines. ${ }^{3}$ University of South Carolina, Columbia, USA. ${ }^{4}$ University of Washington, Seattle, USA. ${ }^{5}$ Indian Institute of Advanced Studies, Shimla, India.

Submit your manuscript to a SpringerOpen ${ }^{\odot}$ journal and benefit from:

- Convenient online submission

- Rigorous peer review

- Immediate publication on acceptance

- Open access: articles freely available online

- High visibility within the field

- Retaining the copyright to your article

Submit your next manuscript at $>$ springeropen.com 